\title{
Banking Legislation Renewal as a Preventive Effort of Banking Corruption Crime
}

\author{
Felix Dalimartha ${ }^{1}$, Faisal Santiago ${ }^{2}$ \\ Doctoral of Law, Universitas Borobudur Jakarta \\ \{felixunbor@gmail.com ${ }^{1}$, faisalsantiago@borobudur.ac.id $\left.{ }^{2}\right\}$
}

\begin{abstract}
Empirically in Indonesia, banking corruption crime is almost done every year. For that reason, preventive action becomes crucial act to prevent corruption and banking crimes. Banking corruption crime is an action that against the law which usually be done by employees, directors, commissioners, shareholders, and/or banking affiliation parties that caused national financial losses to be the imposition of corruption crime on the party concerned. The stipulation that regulated about banking in Indonesia is occurred in Law Number of 1992 concerning Banking with relation to Law Number 10 of 1998 concerning Amended Law Number Year 1992 concerning Banking. While the stipulation concerning criminal code is stipulated in Law Number 31 of 1999 with conjunction to Law Number 20 of 2001 concerning Eradication of Corruption. As a preventive effort of banking corruption crime, then it needs comprehensive banking legislation renewal within the framework of national development in Indonesia. This research is purposed to understand the banking legislation renewal as a preventive effort of banking corruption crime. This research is a normative legal research which using statutory approach and conceptual.
\end{abstract}

Keywords: Legislation Renewal; Prevention; Criminal Code; Corruption; Banking

\section{Introduction}

The national economic development today shows a direction that is frequently integrated with the regional and international economies which can both support and have an unfavorable impact. Meanwhile, the national economic development continues to move rapidly with complex challenges in line with economic globalization. Therefore, various policy adjustments in the economic sector, including the banking sector, are needed, so that it is expected to improve and strengthen the national economy. Apart from that, criminal acts of banking corruption are in the framework of safeguarding and securing the bank itself.

So far, Act Number 1992 concerning Banking as amended by Act Number 10 of 1998 concerning Amendment to Law Number 1992 concerning Banking regulates conventional banks or commercial banks and Islamic banks along with their authorities, operational requirements, obligations, activities allowed, and what is prohibited. The law also regulates 
the provisions of sanctions related to violations of the banking law including warnings, fines, disqualification, and license revocation to operate as a financial institution.

The banking sector has a strategic position as a financial institution that collects funds from the public. Therefore, a legal instrument is needed that can protect funds safely collected in a bank through professional banking management by prioritizing the principle of prudence in its distribution.

History records the black sheets of Indonesian banking, namely the case of the Bank Indonesia Liquidity Assistance (BLBI) case in 1998 and the Century Bank case in 2008 which caused enormous financial losses to the state. BLBI is an assistance scheme (loan) provided by Bank Indonesia to banks experiencing liquidity problems during the 1998 monetary crisis in Indonesia. This scheme is carried out based on the agreement between Indonesia and the IMF in overcoming the crisis problem. In December 1998, BI had distributed BLBIs amounting to Rp 147.7 trillion to 48 banks. The BPK audit of the use of BLBI funds by the 48 banks concluded that there were indications of irregularities of Rp. 138 trillion [1]. Many of the BLBI funds were misused by the recipients. Many of the distribution processes have been through irregularities committed by bank owners as shareholders.

The resolution of the BLBI problem is still hampered. The government and the owners of BLBI recipient banks have signed several agreements, including the Master Settlement and Acquisition Agreement (MSAA) and the Master Refinancing Agreement and Not Issuance Agreement (MRNIA). It contained an agreement to return the BLBI funds received either through the transfer of assets or take over by the state by converting loans into temporary capital. Even though they were brought into the realm of criminal law, BLBI recipients who paid their obligations, either by payment or transfer of assets then received a Certificate of Settlement which freed them from all criminal lawsuits (Released and Discharged). The basis for providing $\mathrm{R} \& \mathrm{D}$ is the principle of restorative justice which focuses on punishment as an effort to restore the previous condition.

Meanwhile, in the Century Bank case which began on October 31 and November 3, 2008, Century Bank was reported to have experienced serious liquidity problems due to a urgency in which its customers withdrew their savings together. Then the management of Bank Century submitted a Short-Term Loan Facility (FJPP). Bank Indonesia designated Bank Century as a failed bank with systemic impacts and then reported it to the Minister of Finance as Chairman of the Financial System Stability Committee (KSSK). The KSSK meeting decided to provide a bailout or assistance that did not come from contributions payment or premiums but instead used state funds amounting to 632 billion Rupiah to increase capital. LPS also assisted, so that the total assistance received by Century Bank was approximately IDR 6.7 trillion. The sequel was that Bank Century was taken over by LPS and changed its name to Bank Mutiara and now Bank Mutiara has changed to Bank JTrust.

Learning from the case of Century Bank, in 2016 Law Number 9 of 2016 concerning Financial System Crisis Prevention and Management was issued. This Law regulates the role of the Financial System Stability Committee which includes (i) coordination of monitoring and maintenance of financial system stability, (ii) handling of financial system crises, and (iii) handling of systemic bank problems, both under normal financial system stability and crisis conditions. financial system. The emphasis of this law lies in the prevention and handling of systemic bank problems as an important part of the financial system [2].

Then in 2020, the government issued Perppu Number 1 of 2020 concerning State Financial Policy and Financial System Stability for Handling the 2019 Corona Virus Disease (Covid-19) Pandemic and/or in the Context of Facing Threats That Endanger the National Economy 
and/or Financial System Stability, which was later passed into Law Number 2 of 2020 on May $16,2020$.

In this Perppu, the provisions of Article 20 paragraph (3) of Law Number 9/2016, which reads: "Providing short-term liquidity loans or short-term liquidity financing based on sharia principles must be secured by high-quality collateral in the form of securities that have high ratings and are easy to cash". The provisions of Article 20 paragraph (3) become invalid with the existence of Article 16 paragraph (1) of Perppu Number 1 of 2020 which regulates that to support the implementation of the KSSK's authority in the context of controlling financial system stability issues as referred to in Article 15 paragraph (1), Banks Indonesia is given the authority to:

a. provide short term liquidity loans or short-term liquidity financing based on sharia principles to Systemic Banks or banks other than Systemic Banks;

b. provide Special Liquidity Loans to Systemic Banks experiencing liquidity difficulties and do not meet the requirements for providing short-term liquidity loans or short-term liquidity financing based on Sharia principles that are guaranteed by the Government and given based on the KSSK Decree;

c. purchase long-term Government Securities and/or Sharia Securities on the primary market to deal with financial system problems that endanger the national economy, including Government Securities and/or State Sharia Securities issued for a specific purpose, especially in the context of the 2019 Corona Virus Disease pandemic (COVID-19);

d. buy/repo state securities owned by the Deposit Insurance Corporation

e. for the cost of handling solvency problems for Systemic Banks and other Systemic Banks;

f. regulate the obligation to receive and use foreign exchange for residents, including provisions regarding the transfer, repatriation, and conversion of foreign exchange in the framework of maintaining macroeconomic and financial system stability; and

g. provide access to funding for corporations / private companies through Government Securities repo or State Sharia Securities owned by the corporation / private sector through banking.

The provisions of Article 20 paragraph (3) of Law no. 9 of 2016 have raised concerns for some parties about the emergence of a new BLBI. Regarding Perppu No.1 / 2020, the PKS Faction firmly refused. Even the Deputy Chairperson of the PKS Faction Ecky Awal Muharam, the bail-out scheme always has the potential to create scandals of abuse of state financial power over the handling of crises which have caused huge costs and have reminded the public of the trauma of the 1997-1998 economic crisis. This deviation has cost the country more than Rp. 650 trillion-plus the interest expense. This heavy burden is then borne by the people as a whole through sustainable tax burdens and inflation. A handful of conglomerate groups enjoyed the unfair policies of the BLBI and Recap Bonds facilities and remained the masters of capital after the Reformation until now. They still have the privilege of being an economic and capital oligarchy that even affects the social and political landscape today. PKS rejects the bail-out scheme from state finances for the loss of private companies, be they banks, financial institutions, or other companies [3].

To prevent the reoccurrence of the cases that occurred above, it is necessary to improve banking legislation through updating banking legislation. The importance of reforming banking legislation is one of which aims to prevent previous banking corruption crimes such as the BLBI and Century Bank cases so that state financial losses can be minimized. Based on the above background, transforming banking legislation as an effort to prevent criminal acts of banking corruption is important. It is necessary to analyze it more focused and deeply from a statutory perspective. 


\section{Research Problem}

According to the background which has been explained above, then the research problem could be formulated as bellow:

How is the banking legislation renewal as preventive effort of banking corruption crime?

\section{Research Method}

This research is a normative legal research. A normative research is known as doctrinal research, namely a research which examination object is statutory regulation documents and library material [4].

\section{Discussion}

According to Article 1 number 1 of the Banking Law, banking is anything that depends on a bank, including governance, activities, methods, and processes in its business activities. Meanwhile, the definition of a bank is a business entity that collects funds from the public in the form of deposits and distributes them to the public in the form of credit and or other forms to improve the standard of living of the people at large [5].

Banks are financial institutions that carry out business activities in the financial services sector, in particular, collecting and channeling public funds (financial intermediary). Apart from being a financial intermediary, banks also provide other supporting services including money transfer services (transfers), collection (collection), clearing (clearing), sales of foreign currency (foreign currency), safe deposit boxes, travelers' checks, bank cards, letters. of credit (L / C), bank guarantee, and bank references [6]. From these business activities, the bank benefits from administration fees, commissions, rent, and other expenses. This advantage in the banking world is known as fee-based.

Banks are intermediary institutions that in operating their business activities depend on public funds and trust, both from within and from abroad. In carrying out these business activities, banks face various credit risks, market risks, operational risks, and reputation risks. Many provisions are regulating the banking sector to protect the interests of the public, including provisions regulating the obligation to meet minimum capital according to the conditions of each bank, making the banking sector a highly regulated sector. Besides, banking is a sector that is vulnerable to criminal acts of banking corruption.

Empirically, banking corruption is committed through fraud, burglary, and looting, which often occurs in Indonesia. Almost every year this happens to both large and small banks. Whether done by parties within the bank or by parties outside the bank. Either done by the bank owner or by bank employees.

Concerning a criminal act, the basis for the conviction of an act is closely related to the problem of the source of law or the legality of the basis for declaring an act as a criminal act or not [7]. The definition of a criminal offense in the Criminal Code is not formulated explicitly, but only states the elements of the crime. In Article 12 of the Bills on the Criminal Code, the concept has been formulated or formulated, which states that:

a. A criminal act is an act that is punishable by statutory sanction and/or action. 
b. To be declared as a Criminal Action, an act that is subject to criminal sanctions and/or acts by statutory regulations must be against the law or contrary to the laws that live in society.

c. Every criminal act is always against the law unless there is justification.

Meanwhile, the definition of corruption in essence has a broad dimension, therefore it is necessary to elaborate etymologically and juridically and synergize it with the views of experts on what is meant by corruption.

According to Black's Law Dictionary, corruption is an act that is carried out to provide an unofficial advantage with the rights of another party by illegally using his position or character to get an advantage for himself or others [8]. Corruption is the misappropriation or embezzlement of state or company money as a place for someone to work for personal gain or other people [9]. The criminal act of corruption (Tipikor) is a violation of the rights of the community, both economically and socially. Corruption is no longer classified as an ordinary crime but has become an extra-ordinary crime.

Corruption in the juridical sense has been emphasized in Law Number 31 of 1999 in conjunction with Law Number 20 of 2001 concerning the Eradication of Corruption Crimes, that corruption is:

Article 2 paragraph (1)

Anyone who unlawfully commits an act of self-enrichment or a corporation that can harm the state finances or the country's economy.

Article 3

Anyone who, intending to benefit himself or another person or a corporation, misuses the authority, opportunity, or media available to him because of his position or status which may harm the state finances or the state economy.

Furthermore, according to the Elucidation of Article 2 paragraph (2) earlier, what is meant by "illegally" in this Article includes acts against the law in a formal sense as well as in a material sense, namely even though the act is not regulated in statutory regulations, if the act is considered disgraceful because it is not following the sense of justice or the norms of social life in society, then the act can be punished. In this provision, the word "can" before the phrase "detrimental to the country's finances or economy" indicates that the criminal act of corruption is a formal offense, that is, the existence of a corruption crime is sufficient by affecting the elements of the act that have been formulated without the consequence.

Roeslan Saleh argued, according to the teaching against the law, what is called against material law is not only against the written law but also against the unwritten law [10]. On the other hand, the lesson against formal law argues that against the law is contrary to written law only. So according to instructions material, in addition to fulfilling formal requirements, namely fulfilling all the elements mentioned in the formulation of offenses, actions must be perceived by society as prohibited or indecent.

The occurrence of banking corruption crime in Indonesia is due to the weakness of banking legal instruments relating to the prevention of banking corruption crimes, which mostly occur by internal bank-affiliated parties. According to the 1998 Banking Law, Article 1 point 22 referred to as Affiliated Parties are:

a. Members of the Board of Commissioners, supervisors, Directors or their proxies, officers or employees of the bank;

b. Members of the management, supervisors, managers or proxies, officers, or bank employees, especially for banks that are in the form of a cooperative under the prevailing laws and regulations;

c. Parties providing services to banks, including public accountants, appraisers, legal consultants, and other consultants; 
d. Parties who according to Bank Indonesia's assessment participate in influencing bank management, including but not limited to shareholders and their families, the families of the Commissioners, the families of supervisors, the families of the Directors, the families of the managers.

An example of banking corruption in Indonesia is the Century Bank in 2008. From the Bank Century bailout case which caused serious losses to the country's finances, there is one thing that deserves attention to be studied and discussed, namely Robert Tantular's position at Century Bank. From the court's decisions regarding this case, it is clear that Robert Tantular is an affiliate of Bank Century. Robert Tantular was charged and convicted under Article 50A of Law Number 7 of 1992 concerning Banking in conjunction with Law Number 10 of 1998 concerning Amendment to Law Number 7 of 1992 concerning Banking which reads:

"Shareholders who deliberately order the Board of Commissioners, Directors, or bank employees to take or not take action that results in the bank not taking the necessary steps to ensure bank compliance with the provisions of this Law and other applicable laws and regulations for a bank, is threatened with imprisonment of at least 7 (seven) years and a maximum of 15 (fifteen) years and a fine of at least Rp.10,000,000,000.00 (ten billion rupiahs) and a maximum of Rp.200,000,000,000.00 (two hundred billion rupiahs)".

As it is known that Robert Tantular is the Director of PT. Century Mega Investindo, which is a shareholder of PT. Century Bank, Tbk. According to the provisions of Law Number 40 of 2007 concerning Limited Liability Companies, Article 1 number 5 states that "The Board of Directors is the Company's organ which is authorized and fully responsible for the management of the Company for the benefit of the Company, under the purposes and objectives of the Company and representing the Company, both inside and outside the court under the provisions of the articles of association" and Article 98 paragraph (1) which states that "the Board of Directors represents the Company both inside and outside the court". Thus, Robert Tantular's actions as Director of PT. Century Mega Investindo is a legitimate act by the PT.

Furthermore, the Banking Law does not limit how much share ownership a person or institution has to become an affiliated party. Thus, PT. Century Mega Investindo can be said to be an affiliated party even though it is only a minority shareholder in Bank Century. From these considerations, Robert Tantular may be subject to Article 50A.

The question is, what if Robert Tantular is not a Director of PT. Century Mega Investindo, but the shareholders or the families of the shareholders. By using the argument of the Limited Liability Company Law, a shareholder is not entitled to act on behalf of the company in which he/she is a shareholder, except for shareholders who are concurrently serving as directors. The Banking Law does not regulate the shareholders of a company's shareholders as affiliated parties because in Indonesian law the concept of a parent company or holding company is not explicitly recognized.

$A$ holding company is a company that owns and commands [11] which in such a situation there can be an arrangement of several PTs which are juridically independent legal subjects which have nothing to do with each other, but from an economic point of view, they are an economic unit. This PT arrangement is what the Dutch literature calls a "concern" relationship or group company [12]. Learning from the example of the Century Bank case above, regulatory reforms or reforms of banking legislation must be carried out immediately. This is considering so that cases such as the BLBI in 1998 and Century Bank in 2008 do not recur.

According to Bagir Manan, legal reform is an internal function of legislation. The legislation is an effective instrument in law reform compared to the use of customary law or jurisprudential law. The formation of laws and regulations can be planned as well as the legal 
reforms. The legislation does not only perform the function of updating (existing) laws and regulations. Legislation can also be used as a method of updating jurisprudence, customary law, or customary law [13]. The restoration here is the renewal of the Banking Law by amending articles, deleting articles, and adding new stipulations in the form of new articles or the form of insertions in existing articles. The reformation is intended as an effort to prevent banking corruption crime with new provisions as a binding positive legal instrument.

One of the reforms to the Banking Law is the addition of a new provision in the form of insertion into an existing article, namely by entering the term controlling or controlling entity other than affiliated parties in Article 1 of the Banking Law. As it is known, Article 1 of the Banking Law contains only the definition of affiliation, while the definition of the controlling clause does not yet exist.

The definition of a controller has been stated in Law Number 40 of 2014 concerning Insurance, Article 1 number 19, which reads: "A controller is a person who directly or indirectly can determine the board of directors, the board of commissioners, or equivalent to directors or board of commissioners. in a legal entity in the form of a cooperative or joint venture and/or influence the actions of the board of directors, the board of commissioners, or the equivalent of the board of directors or the board of commissioners in a legal entity in the form of a cooperative or joint venture". This definition may apply mutatis mutandis to the Banking Law.

Furthermore, it is stated about the responsibility of controllers in the Insurance Law, Article 15 which reads: "The controller shall be responsible for the losses of the Insurance Company, Sharia Insurance Company, reinsurance company or Sharia reinsurance company caused by the Party under his control".

Meanwhile, according to the Financial Services Authority (OJK) Regulation Number 9 / POJK.04 / 2018 concerning Takeover of a Public Company, Article 1 point 4 states that a Controller of an Open Company, hereinafter referred to as a Controller, is a Person, either directly or indirectly:

a. Owning shares of a Public Company of more than 50\% (fifty percent) of all shares with fully paid voting rights; or

b. Has the ability to determine, either directly or indirectly, by whatever means the management and/or policies of the Public Company.

In addition to clauses on controlling phrases that must be included in the revision of the Banking Law are clauses on phrases concerning the responsibility of controllers in the concept of the Banking Bill as already contained in the Insurance Law.

The controller can be determined by the Bank concerned, with the approval of the Financial Services Authority (OJK) and/or Bank Indonesia, without eliminating the rights of OJK and/or Bank Indonesia to determine for themselves who is the controller of a Bank. For legal protection for controllers, a bank must report to the authorities if the controller that it determines itself or the controller determined by the regulator no longer performs its function as a controller, whether due to health reasons, age, business reasons, and others. However, regulators can assign controllers to their original positions if according to the regulator the controllers are still carrying out their functions secretly.

Furthermore, a Controller does not need to go through a fit and proper test before becoming a controller in a bank. This is done to prevent the bank's attempts to thwart the controllers determined by the authorities, both OJK and BI, through failure in the fit and proper test. However, the controller is obliged to share responsibility for bank losses. Furthermore, renewal of banking legislation is an amendment to criminal provisions with the addition of the phrase "controlling" in Article 50A of the Banking Law, so that it reads; 
Shareholders and/or controllers who deliberately order the Board of Commissioners, Directors, or bank employees to take or not take action that results in the bank not taking the necessary steps to ensure bank compliance with the provisions of this law and other statutory provisions applicable to the bank, is threatened with imprisonment of at least 7 (seven) years and a maximum of 15 (fifteen) years and a fine of at least Rp.10,000,000,000.00 (ten billion rupiahs) and a maximum of Rp.200,000,000,000.00 (two hundred billion rupiahs).

Therefore, it is hoped that in the future every person who has authority over a bank can be held accountable if the bank experiences a loss due to his mistake. This is intended so that in the future the bail-in and bail-out systems in the banking sector in Indonesia can be used according to their intended purpose, not being misused for the benefit of certain parties during a difficult economic situation, amid losses experienced by the customers of the bank concerned.

\section{Conclusion and Suggestion}

\subsection{Conclusion}

Banking history records the black sheet of Indonesian banking with cases BLBI and Century Bank on 2008 which is banking corruption crime. That banking corruption crime is done by the affiliated parties. In the Banking legislation, the affiliated parties have not been expanded nor accommodate the provision of controls as it is stated in the law of the insurance system. The regulators are the parties who responsible besides the affiliated parties that if banking corruption crime has occurred which divert the using and/or the allocation of banking fund that should be allocated and based on the careful principle.

\subsection{Suggestion}

There is a need for the restoration of banking legislation through the formation of new banking laws and regulations, one of which is the addition of a clause or phrase that defines "controlling" in the Banking Bill. Including changes to affiliated party elements that must be expanded. Besides, there must also be clauses/articles regarding the responsibility of controllers in the Banking Bill that have been included in the DPR RI National Legislation Program list. These reforms are very important because cases such as the 1998 BLBI and the 2008 Century Bank cases are not repeated. This is an effort to prevent criminal acts of banking corruption by affiliated parties.

\section{References}

[1] Wikipedia.: Bantuan Likuiditas Bank Indonesia. Retrieved from https://id.wikipedia.org/wiki/Bantuan_Likuiditas_Bank_Indonesia\#: :text $=$ BLBI\%20a dalah\%20skema\%20bantuan\%20(pinjaman,krisis\%20moneter\%201998\%20di\%20Ind onesia.\&text $=$ Pada\%20bulan\%20Desember\%201998\%2C\%20BI,7\%20triliun\%20kep ada\%2048\%20bank

[2] Undang-Undang Republik Indonesia Nomor 9 Tahun 2016 tentang Pencegahan dan Penanganan Krisis Sistem Keuangan. 
[3] Muharam, Ecky Awal.: PKS Tolak Perppu No. 1 Tahun 2020. Retrieved from https://www.suarainvestor.com/pks-tolak-perppu-no-1-tahun-2020/, 5 Mei 2020

[4] Soejono dan H. Abdurahman.: Metode Penelitian Hukum. Rineka Cipta, Jakarta (2003)

[5] Undang-Undang Republik Indonesia Nomor 10 Tahun 1998 tentang Perubahan Undang-Undang Nomor Tahun 1992 tentang Perbankan.

[6] Gazali, Djoni S. dan Rachmadi Usman.: Hukum Perbankan. Cetakan Pertama. Sinar Grafika, Jakarta (2010).

[7] Arief, Barda Nawawi.: Perkembangan Sistem Pemidanaan di Indonesia. Badan Penerbit Undip, Semarang (2009).

[8] Rohim.: Modus Operandi Tindak Pidana Korupsi, Pena Multi Media, Depok (2008).

[9] Sudarsono.: Kamus Hukum. Rineka Cipta, Jakarta (2009)

[10] Saleh, Roeslan.: Sifat Melawan Hukum dari Perbuatan Hukum Pidana. Aksara Baru, Jakarta (1987).

[11] Fuady, Munir.: Perseroan Terbatas Paradigma Baru. Citra Aditya Bakti, Bandung (2003).

[12] Prasetya, Rudhi.: Kedudukan Mandiri Perseroan Terbatas. Citra Aditya Bakti, Bandung (2001)

[13] Manan, Bagir.: Dasar-Dasar Perundang-Undangan Indonesia. Ind-Hill.Co, Jakarta (1992). 